\title{
Phenobarbital influence on neuromuscular block produced by rocuronium in rats ${ }^{1}$
}

\author{
Influência do fenobarbital no bloqueio neuromuscular produzido pelo rocurônio em ratos
}

\begin{abstract}
Angélica de Fátima de Assunção Braga', Caroline Coutinho de Barcelos" ${ }^{\text {II }}$ Franklin Sarmento da Silva Braga ${ }^{\mathrm{III}}$, Samanta Cristina Antoniassi Fernandes"I, Yoko Oshima Franco ${ }^{\mathrm{IV}}$, Mario Mantovani ${ }^{\text {, }}$, Léa Rodrigues Simioni ${ }^{\mathrm{I}}$
\end{abstract}

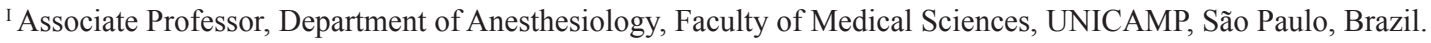

${ }^{\text {II }}$ Master, Department of Pharmacology, UNICAMP, São Paulo, Brazil.

III PhD, Department of Anesthesiology, Faculty of Medical Sciences, UNICAMP, São Paulo, Brazil.

IV PhD, Department of Pharmacology, UNICAMP, São Paulo, Brazil.

${ }^{v}$ Full Professor, Department of Surgery, UNICAMP, São Paulo, Brazil.

\begin{abstract}
Purpose: To evaluate in vitro and in vivo neuromuscular blockade produced by rocuronium in rats treated with Phenobarbital and to determine cytochrome P450 and cytochrome b5 concentrations in hepatic microsomes. Methods: Thirty rats were included in the study and distributed into 6 groups of 5 animals each. Rats were treated for seven days with phenobarbital (20 mg/kg) and the following parameters were evaluated: 1) the amplitude of muscle response in the preparation of rats exposed to phenobarbital; 2) rocuronium effect on rat preparation exposed or not to phenobarbital; 3) concentrations of cytochrome P450 and cytochrome b5 in hepatic microsomes isolated from rats exposed or not to phenobarbital. The concentration and dose of rocuronium used in vitro and in vivo experiments were $4 \mu \mathrm{g} / \mathrm{mL}$ and $0,6 \mathrm{mg} / \mathrm{kg}$, respectively. Results: Phenobarbital in vitro and in vivo did not alter the amplitude of muscle response. The neuromuscular blockade in vitro produced by rocuronium was significantly different $(\mathrm{p}=0.019)$ between exposed $(20 \%)$ and not exposed (60\%) rats; the blockade in vivo was significantly greater $(\mathrm{p}=0.0081)$ in treated rats (93.4\%). The enzymatic concentrations were significantly greater in rats exposed to phenobarbital. Conclusions: Phenobarbital alone did not compromise neuromuscular transmission. It produced enzymatic induction, and neuromuscular blockade in vivo produced by rocuronium was potentiated by phenobarbital.
\end{abstract}

Key words: Phenobarbital. Neuromuscular Blocking Agents. Rats.

\section{RESUMO}

Objetivo: Avaliar in vitro e in vivo o bloqueio neuromuscular produzido pelo rocurônio em ratos tratados com fenobarbital e determinar as concentrações de citocromo P450 e b5 em microssomos hepáticos. Métodos: Trinta ratos foram incluídos no estudo e distribuídos em seis grupos de cinco animais cada. Ratos foram tratados por sete dias com fenobarbital (20 mg/kg) e avaliou-se: 1) amplitude das respostas musculares em preparação de ratos expostos ao fenobarbital; 2) o efeito do rocurônio em preparações de ratos expostos ou não ao fenobarbital; 3) as concentrações de citocromo P450 e b5 em microssomos isolados de fígados dos ratos expostos ou não ao fenobarbital. A concentração e dose de rocurônio utilizadas nos experimentos in vitro e in vivo foram respectivamente de $4 \mu \mathrm{g} / \mathrm{mL}$ e $0,6 \mathrm{mg} / \mathrm{kg}$. Resultados: In vitro e in vivo, o fenobarbital não alterou a amplitude das respostas musculares. In vitro, o bloqueio produzido pelo rocurônio foi significativamente diferente $(\mathrm{p}=0.019)$ entre expostos (20\%) e não expostos (60\%); in vivo o bloqueio foi significativamente maior ( $\mathrm{p}=0.0081)$ nos ratos tratados $(93,4 \%)$. As concentrações enzimáticas foram significativamente maiores nos ratos expostos ao fenobarbital. Conclusões: O fenobarbital isoladamente não comprometeu a transmissão neuromuscular. Ocasionou indução enzimática, e in vivo o bloqueio com o rocurônio foi potencializado pelo fenobarbital.

Descritores: Fenobarbital. Bloqueadores Neuromusculares. Ratos.

${ }^{1}$ Research performed at Laboratory of Neuromuscular Junction, Department of Pharmacology, State University of Campinas (UNICAMP), São Paulo, Brazil. 


\section{Introduction}

Pharmacokinetic and pharmacodynamic characteristics of neuromuscular blocking agents, can be modified by drugs used in periods pre and post-operatory. Among these drugs are local anesthetics, volatile anesthetic agents, antibiotics aminoglycosides, anticonvulsants, antiarrhythmic, magnesium, lithium, calcium channel blockers and others ${ }^{1-12}$. Although countless studies have been accomplished to investigate anticonvulsants effects in the neuromuscular transmission and its interaction with neuromuscular blocking, the results are contradictory ${ }^{6-15}$.

The study accomplished in vitro and in vivo, has for objective to evaluate in rats treated for seven days with phenobarbital: the effect in the neuromuscular transmission and its influence in the neuromuscular blockade produced by the rocuronium; as well as to determine the cytochrome P450 and b5 concentrations in hepatic microsomes.

\section{Methods}

It treats of an experimental in vitro and in vivo study and the procedures used were in agreement with the Ethical Principles for Animal Research established by Brazilian College for Animal Experimentation (COBEA) and were approved by the institutional Committee for Ethics in Animal Research (State University of Campinas - UNICAMP) - protocol $n^{\circ} 862-2$. Were used male rats of Wistar lineage, with weight among 180 - 250g. The animals were treated for seven days with phenobarbital (20 $\mathrm{mg} / \mathrm{kg}$ ) by the gavage method, maintained in cages, in controlled temperature and illumination (12-h light-dark cycle) and they received water and ration ad libitum.

\section{Study of muscular responses}

For in vitro study was used the preparation of rat phrenic nerve-hemidiaphragm $(n=15)$. The animals under anesthesia with urethane $(1,2 \mathrm{mg} / \mathrm{kg}$, through intraperitoneal route), were sacrificed in the eighth day after treatment with phenobarbital, being followed by the section of neck vessels, and the preparation was set up in agreement with the technique described by Bulbring ${ }^{16}$. The preparation was suspended under a constant tension of $5 \mathrm{~g}$ in a $40 \mathrm{ml}$ organ bath containing aerated $\left(95 \% \mathrm{O}_{2}\right.$ $5 \% \mathrm{CO}_{2}$ ) Tyrode solution $\left(\mathrm{pH} 7.4,37^{\circ} \mathrm{C}\right)$ of the following composition (mM): $\mathrm{NaCl} 137 ; \mathrm{KCl} 2,7 ; \mathrm{CaCl}_{2} 1,8 ; \mathrm{NaHCO}_{3}$ 11,9; $\mathrm{MgCl}_{2} 0,25 ; \mathrm{NaH}_{2} \mathrm{PO}_{4} 0,3$ and glucose 11 . The nerve was placed over platinum probes connected to a Grass S48 stimulator. The diaphragm was held by its tendinous portion under constant tension through a wire connected to a Load Cell BG50 GMS isometric transducer. The diaphragm was submitted to an indirect stimulation frequency of $0.1 \mathrm{~Hz}$ lasting $0.2 \mathrm{msec}$ and the tension variations produced by diaphragmatic contractions were recorded by a Gould RS 3400 physiographer.

For in vivo study $(\mathrm{n}=15)$ the sciatic external popliteal nerve - tibialis anterior muscle preparation, was set up according to technique proposed by Leeuwin and Wolters ${ }^{17}$. The rats were anesthetized with urethane $(1,2 \mathrm{mg} / \mathrm{kg})$, submitted to tra- cheostomy and maintained in ventilation mechanics with Hugo Basile respirator (mod. 7025), regulated to maintain current volume of $1,2 \mathrm{~mL} / \mathrm{kg}$ of corporal weight and breathing frequency of 70 movements $/ \mathrm{min}$. Tibialis anterior muscle tendon and sciatic nerve were dissectioned, sectioned and accomplished for the member fixation to a cork base. Tendon of tibialis anterior muscle was connected to an isometric transducer (BG 50g) and this to the physiographer (GOULD RS 3400). The sciatic nerve distal stump was stimulated (stimulator grass S48) through electrodes connected to it, being used supramaximal stimulation of $0,2 \mathrm{~ms}$ of duration and frequency of $0,5 \mathrm{~Hz}$. After the registration of the controls answer and the verification of the perfect state of the preparation, rocuronium was injected in the penian vein. In the preparations in vitro and in vivo were appraised: 1) amplitude of the muscular answers in preparation of rats previously exposed to phenobarbital; 2) the rocuronium effect in the muscular answers in preparations of rats previously exposed or not to phenobarbital.

In the studies in vitro and in vivo the concentration and the dose used of rocuronium were of $4 \mu \mathrm{g} / \mathrm{mL}$ and $0,6 \mathrm{mg} /$ $\mathrm{kg}$, respectively. The muscular answers to the indirect stimulation were registered and evaluated before and 60 minutes after the injection of the rocuronium.

\section{Study of cytochrome P450 and b5 concentrations}

For the determination of cytochrome P450 and b5 concentrations in the hepatic microsomes, were used livers extracted from rats exposed previously to phenobarbital, used for in vitro and in vivo muscular responses study. It was constituted a group control $(n=5)$ that just received saline solution for 7 days. It was realized the following procedure: exhibition of the liver after ventral incision; with a catheter was injected $50 \mathrm{~mL}$ of physiologic solution $\mathrm{NaCl} 0,9 \%$ without heparin in the heart ventricle, until the liver to obtain a whitish coloration, when it was extracted and frozen in liquid nitrogen. Were isolated hepatic microsomes obtained from individual livers. Tissues were hand homogenized with potassium phosphate buffer that were centrifuged at $10000 \mathrm{x}$ g for 20 minutes (Centrifuge Beckman Avanti J-20 XPI). The supernatant was collected and ultracentrifuged at $100000 \times \mathrm{g}$ for 1 hour. Microsomes were stored in freezer to $80^{\circ} \mathrm{C}$ for subsequent dosage of total proteins, where Bradford's method colorimeter was used (1976) with BSA as standard. The specific concentrations of cytochrome $\mathrm{P} 450$ and $\mathrm{b} 5$ were determinated using b5 concentration with NADH $(1 \mathrm{mM})$ as reducer, and the concentration of P450 with DTN $(2 \mathrm{mM})$ as reducer and CO (carbon monoxide) as ligand. For analysis a plate spectrophotometer was used (Biotek Powerwave 2). Cytochromes concentrations were calculated according to Lambert-Beer formula (A / C.L.E), and related with the concentration of total proteins of the microsomes sample. Where:

$\mathrm{A}=$ delta absorbance

$\mathrm{E}=$ specific absorbance: $\mathrm{P} 450=91 / \mathrm{mM} \mathrm{cm}$ and b5 $=112 / \mathrm{mM} \mathrm{cm}$;

$\mathrm{L}=$ cuvette optical track, cm;

$\mathrm{C}=$ concentration of microsomal proteins $(\mathrm{mg}$ protein $/ \mathrm{mL})$. 


\section{Statistical analysis}

The results were expressed in averages and standard deviations. Amplitude of muscular responses was compared before and 60 minutes after drugs administration. The concentrations of $\mathrm{P} 450$ and $\mathrm{b} 5$ obtained in liver of exposed rats to phenobarbital were compared with the one of the control group (saline solution). It was used test t Student, being assumed significance level of $5 \%(\alpha=5 \%)$. The power of the test was calculated and it was obtained $\beta>20 \%$ (power $>80 \%$ ).

\section{Results}

In the experiments in vitro and in vivo, there were insignificant alterations in the amplitude of muscular responses to indirect stimulation, in the rats previously exposed to phenobarbital (Figure 1).

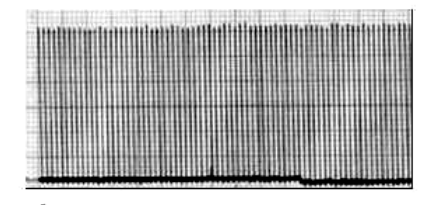

A
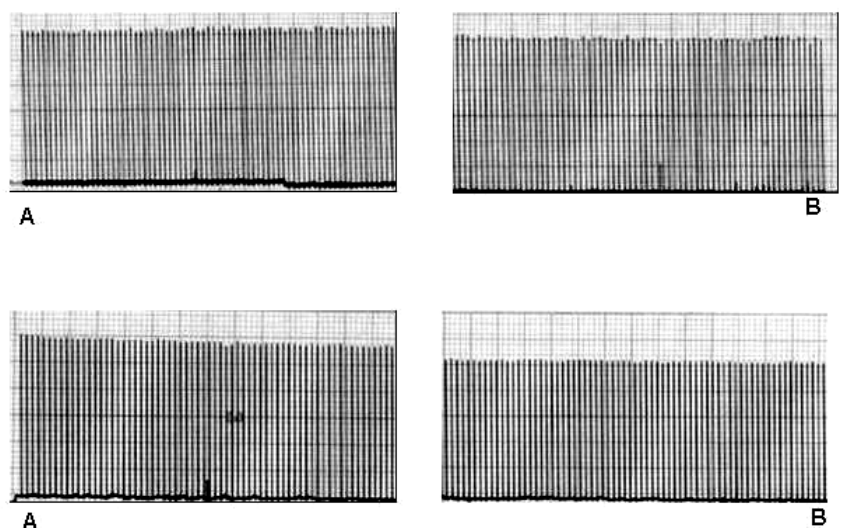

FIGURE 1 - Muscular responses to indirect stimulation of in vitro $(\mathrm{n}=5)$ phrenic nerve-diaphragm preparation (upper tracing) and of in vivo $(\mathrm{n}=5)$ sciatic nerve-tibialis anterior muscle preparation (lower tracing) of rats previously exposed to phenobarbital $(20 \mathrm{mg} / \mathrm{kg}) . \mathbf{A}=$ stimulation beginning; $\mathbf{B}=60$ minutes of stimulation

The neuromuscular blockade produced by rocuronium in diaphragm of rats not exposed to phenobarbital was of $(69,70 \% \pm 10,10 \%)$, with significant difference $(p=0.019)$ in relation to the observed in the preparations of exposed rats to phenobarbital $(20,0 \% \pm 7,82 \%)$. The amplitude of muscular responses at 60 minutes after the addition of rocuronium were $40 \%$ and $80 \%$ in the preparation not exposed and exposed to Phenobarbital, respectively (Figure 2).

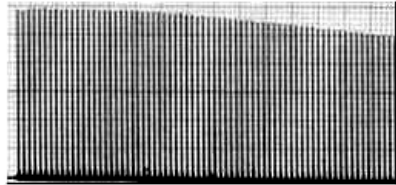

A

B
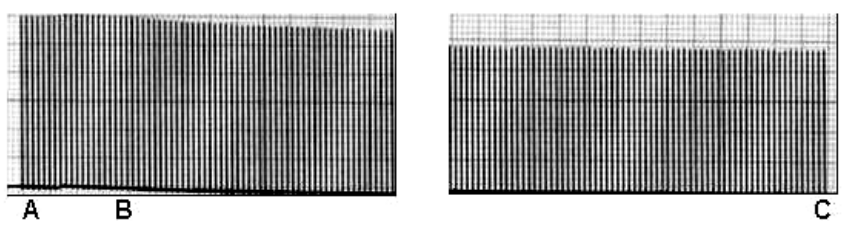

FIGURE 2 - Effect of rocuronium $(4 \mu \mathrm{g} / \mathrm{mL})$ in muscular responses to indirect stimulation of in vitro phrenic nerve-diaphragm preparation of rats not exposed $(\mathrm{n}=5)$ (upper tracing-neuromuscular blockade of $60 \%$ ) and previously exposed $(\mathrm{n}=5)$ to phenobarbital $-20 \mathrm{mg} / \mathrm{kg}$ (lower tracing-neuromuscular blockade of $20 \%$ )). $\mathbf{A}=$ stimulation beginning; $\mathbf{B}=$ rocuronium addition; $\mathbf{C}=60$ minutes of stimulation

In experiments in vivo, accomplished in sciatic external popliteal nerve - tibialis anterior muscle preparation, the blockade produced by rocuronium $(93.4 \pm 4.21 \%)$ was significantly larger $(\mathrm{p}=0.0081)$ in rats exposed to phenobarbital, in relation to the observed in not exposed $(66.7 \pm 6,92 \%)$. The amplitude of muscular responses at 60 minutes after the addition of rocuronium were $33.3 \%$ and $6.6 \%$ in the preparations not exposed and exposed to Phenobarbital. Respectively (Figure 3).
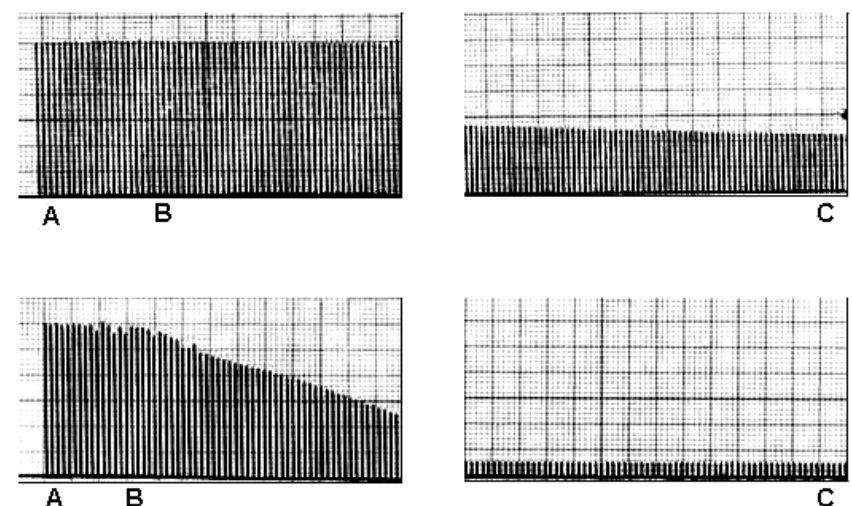

FIGURE 3 - Effect of rocuronium $(0,6 \mathrm{mg} / \mathrm{kg})$ in muscular in vivo responses to indirect stimulation in sciatic nerve - tibialis anterior muscle preparation of rats not exposed $(\mathrm{n}=5)$ (upper tracing-neuromuscular blockade of $66.7 \%)$ and previously exposed $(n=5)$ to phenobarbital $20 \mathrm{mg} / \mathrm{kg}$ (lower tracing-neuromuscular blockade of $93.4 \%$ ). $\mathbf{A}=$ stimulation beginning; $\mathbf{B}=$ rocuronium addition; $\mathbf{C}=60$ minutes of stimulation 
Cytochromes P450 and b5 concentrations in hepatic microsomes in the control group (saline solution) were 0,43 and $0,45 \mathrm{nmol} / \mathrm{mg}$ protein, respectively. In the rats exposed to phenobarbital cytochromes $\mathrm{P} 450$ and b5 concentrations were, respectively 0,69 and $0,62 \mathrm{nmol} / \mathrm{mg}$ protein, with significant difference $(p=0.022)$ in relationship observed in the control group.

\section{Discussion}

Although exists many studies that describe interaction among anticonvulsants and neuromuscular blocking agents there is not in the literature works that show the influence of phenobarbital in the blockade produced by the different neuromuscular blocking agents, with consequent modification of pharmacodynamics and pharmacokinetics properties of these agents.

Phenobarbital is a long-acting barbiturate, indicated as hypnotic or sedative in the insomnia treatment, preoperative mitigation and at focal and generalized tonic-clonic convulsive emergencies. Its mechanism is not due just to its interaction with GABA, being probable that can also act when inhibiting the excitatory synaptic answers. Additionally it affects membranes excitability through an action on the voltage-dependent sodium channels, that transport current into the cell, necessary for generation of the action potential ${ }^{18}$.

In general, anticonvulsants, by itselves can act in neuromuscular junction, to modify or even not to interfere with the pharmacodynamics and pharmacokinetics properties of neuromuscular blocking agents $\mathrm{s}^{6-15,19-21}$.

Aldernice and Trommer ${ }^{21}$, studied the effects of different anticonvulsants in frog neuromuscular junction, and they observed that these drugs perform different action mechanisms in relation to nervous terminal acetylcholine liberation. Phenobarbital, unlike carbamazepine, increases the neurotransmitter release, it reduces the amplitude of the miniature end-plate potentials without however to alter the amplitude of the endplate potentials.

Among anticonvulsants adverse effects, it is frequent muscular weakness, that can be result of the spontaneous decrease or evoked quantal release of acetylcholine ${ }^{19,21}$.

Resistance to neuromuscular blocking agents it is not clearly elucidated. The aetiology of this interaction seems to be multifactorial and some possible mechanisms can be involved: enzymatic induction with increase of the clearance and hepatic metabolism; increase in alpha-1-Glicoprotein acid concentration resulting of larger protein connection, smaller fraction free from cationic drugs and alteration in the distribution. In the neuromuscular junction, the interaction can be due to the action in the nervous terminal, in the synaptic cleft or in the postsynaptic membrane, with consequent alteration in the nerve action potential, in the synthesis, liberation or enzymatic hydrolysis of acetylcholine, in the calcium efflux, or even for alteration in the number and in the sensibility of the nicotinic receivers, besides could cause no competitive ionic channels blockade $6-7,19,25$.

Exist evidences that the resistance to neuromuscular blocking agents, particularly aminosteroids, observed in chronic patients treated with anticonvulsants, be due to a larger hepatic metabolism, consequent to the enzymatic induction with increased inactivation and elimination of these drugs ${ }^{6,22,25}$.

Differently of the observed in anticonvulsants chronic exposition, experimental studies accomplished in animals and in humans clinical assays, showed neuromuscular blockade potentiated for the acute administration of several anticonvulsants drugs $^{9,11-13}$. Potentiation of pre-existent neuromuscular blockade, caused by anticonvulsant acute administration can be attributed to the fact of these drugs compete with neuromuscular blocking agents moving them from the plasmatic proteins stimulation site with consequent increase of the free active fraction ${ }^{12}$. Other mechanisms were described in the attempt of explaining this potentiation, having been observed that some anti-epileptic drugs exercise effects pre- and post-junctional blockade, stabilizer of neuronal membrane altering the transmembrane flow of íons sodium, potassium and calcium, besides reducing acetylcholine synthesis and liberation ${ }^{9,11,19}$.

Several studies describe larger resistance to neuromuscular blocking agents in animals and patients chronic exposed to anticonvulsivantes $6-8,10,11,20,24,26$. In this study, however, was observed that phenobarbital in the employed dose, did not potentiated the neuromuscular blockade produced by rocuronium in the preparations in vitro, and it potentiated the blockade in the experiments in vivo. This findings is associated with the enzymatic induction evidenced by the increase of cytochromes $\mathrm{P} 450$ and b5 reductase. The attempt to extrapolate and correlate the results obtained experimentally with the clinical picture is a difficult task but the knowledge of mechanism of interaction between anticonvulsants and neuromuscular blockers by the anesthesiologist has an important role in patient care, emphasizing the need to monitor neuromuscular transmission when neuromuscular blockers and anticonvulsants are concomitantly used.

\section{Conclusion}

Phenobarbital alone did not compromise neuromuscular transmission. It produced enzymatic induction, and neuromuscular blockade in vivo produced by rocuronium was potentiated by phenobarbital.

\section{References}

1. Haywood PT, Divekar N, Karalliedde LD. Concurrent medication and the neuromuscular junction. Eur J Anaesthesiol. 1999;16:77-91.

2. Cardoso LSM, Martins CR, Tardelli MA. Efeitos da lidocaína por via venosa sobre a farmacodinâmica do rocurônio. Rev Bras Anestesiol. 2005;55:371-80.

3. Loyola YCS, Braga AFA, Potério GMB, Sousa SR, Fernandes SCA, Braga FSS. Influência da lidocaína no bloqueio neuromuscular produzido pelo rocurônio: estudo em preparação nervo frênicodiafragma de rato. Rev Bras Anestesiol. 2006;56:147-56.

4. Sousa SRS, Braga AFA, Potério GMB, Braga FSS, Loyola YCS, Fernandes SCA. Influência da nifedipina no bloqueio neuromuscular produzido pelo atracúrio e pelo cisatracúrio: estudo em preparações nervo frênico-diafragma de rato. Rev Bras Anestesiol. 2006;56:15767. 
5. Fernandes SCA, Braga AFA, Braga FSS, Loyola YCS, Souza SR, Barcelos CC. Influência do lítio no bloqueio neuromuscular produzido pelo atracúrio e pelo cisatracúrio: estudo em preparações nervo frênicodiafragma de rato. Rev Bras Anestesiol. 2007;57:289-300.

6. Alloul K, Whalley DG, Shutway F, Ebrahim Z, Varin F. Pharmacokinetic origin of carbamazepine-induced resistance to vecuronium neuromuscular blockade in anesthetized patients. Anesthesiology. 1996;84:330-9.

7. Richard A, Girard F, Girard DC, Boudreault D, Chouinard P, Moumdjian R, Bouthilier A, Ruel M, Couture J, Varin F. Cisatracuriuminduced neuromuscular blockade is affected by chronic phenytoin or carbamazepine treatment in neurosurgical patients. Anesth Analg. 2005;100:538-44.

8. Tempelhoff R, Modica PA, Jellish WS, Spitznagel EL. Resistance to atracurium-induced neuromuscular blockade in patients with intractable seizure disorders treated with anticonvulsants. Anesth Analg. 1990;71:665-9.

9. Spacek A, Nickl S, Neiger FX, Nigrovic V, Ullrich OW, WeindmayrGoettel M, Schwall B, Taeger K, Kress HG. Augmentation of the rocuronium-induced neuromuscular block by the acutely administered phenytoin. Anesthesiology. 1999;90:1551-5.

10. Spacek A, Neiger FX, Krenn CG, Hoerauf K, Kress HG. Rocuronium-induced neuromuscular block is affected by chronic carbamazepine therapy. Anesthesiology. 1999;90:109-12.

11. Kim JU, Lee YK, Lee YM, Yang HO, Han SM, Yang HS. The effect of phenytoin on rocuronium-induced neuromuscular block in the rat phrenic nerve-hemidiaphragm preparation. J Neurosurg Anesthesiol. 2005;17:149-52.

12. Gray HS, Slater RM, Pollard BJ. The effect of acutely administered phenytoin on vecuronium-induced neuromuscular blockade. Anaesthesia. 1989;44:379-81.

13. Nguyen A, Ramzan I. Acute in vitro neuromuscular effects of carbamazepine and carbamazepine-10,11-epoxide. Anesth Analg. 1997;84:886-90.

14. Spacek A, Neiger FX, Spiss CK, Kress HG. Atracurium-induced neuromuscular block is not affected by chronic anticonvulsant therapy with carbamazepine. Acta Anaesthesiol Scand. 1997;41:1308-11.
15. Jellish WS, Thalji Z, Brundidge PK, Tempelhoff R. Recovery from mivacurium-induced neuromuscular blockade is not affected by anticonvulsant therapy. J Neurosurg Anesthesiol. 1996;8:4-8.

16. Bulbring E. Observation on the isolated phyrenic nerve-diaphragm preparation of the rat. Br J Pharmacol. 1946;1:38-61.

17. Leeuwin RS, Wolters ECMJ. Effects of corticosteroids on the sciatic nerve-tibialis anterior muscle of rats treated with hemicholinium3. Neurology. 1977;27:171-7.

18. Rang HP, Dale MM, Ritter JM, Moore PK. Fármacos antiepilépticas. In: Rang HP, Dale MM, Ritter JM, Moore PK. Farmacologia. 5ed. Rio de Janeiro: Elsevier Editora Ltda; 2003. p.627-39.

19. Hartman GS, Fiamengo SA, Riker WF Jr. Succinylcholine: mechanism of fasciculations and their prevention by d-tubocurarine or diphenylhydantoin. Anesthesiology. 1986;65:405-13.

20. Kim CS, Arnold FJ, Itani MS, Martyn JA. Decreased sensitivity to metocurine during long-term phenytoin therapy may be attributable to protein binding and acetylcholine receptor changes. Anesthesiology. 1992;77:500-6.

21. Alderdice MT, Trommer BA. Differential effects of the anticonvulsants phenobarbital, ethosuximide and carbamazepine on neuromuscular transmission. J Pharmacol Exp Ther. 1980;215:92-6.

22. Anderson GD. A mechanistic approach to antiepileptic drug interactions. Ann Pharmacother. 1998;32:554-63.

23. Pirttiaho HI, Sotaniemi EA, Pelkonen RO, Pitkänen U. Hepatic blood flow and drug metabolism in patients on enzyme-inducing anticonvulsants. Eur J Clin Pharmacol. 1982;22:441-5.

24. Wright PM, McCarthy G, Szenohradszky J, Sharma ML, Caldwell JE. Influence of chronic phenytoin administration on the pharmacokinetics and pharmacodynamics of vecuronium. Anesthesiology. 2004;100:626-33.

25. Soriano SG, Martyn JA. Antiepileptic-induced resistance to neuromuscular blockers: mechanisms and clinical significance. Clin Pharmacokinet. 2004;43:71-81

26. Hans P, Brichant JF, Pieron F, Pieyns P, Born JD, Lamy M. Elevated plasma alpha 1-acid glycoprotein levels: lack of connection to resistance to vecuronium blockade induced by anticonvulsant therapy. Neurosurg Anesthesiol. 1997;9:3-7.

Conflict of interest: none Financial source: none

\section{Correspondence:}

Angélica de Fátima Assunção Braga

R. Luciano Venere Decourt, 245

13084-040 Campinas - SP Brazil

Phone: (55 19)3289-5092

franklinbraga@terra.com.br

Received: January 10, 2008

Review: February 12, 2008

Accepted: April 17, 2008

\section{How to cite this article}

Braga AFA, Barcelos CC, Braga FSS, Fernandes SCA, Oshima-Franco Y, Mantovani M, Rodrigues-Simioni L. Phenobarbital influence on neuromuscular block produced by rocuronium in rats. Acta Cir Bras. [serial on the Internet] 2008 July-Aug;23(4). Available from URL: http://www.scielo.br/acb 